\title{
Effects of (Ti, W)C Addition on the Microstructure and Mechanical Properties of Ultrafine WC-Co Tool Materials Prepared by Spark Plasma Sintering
}

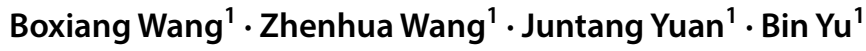 \\ Received: 18 October 2019 / Revised: 25 November 2019 / Published online: 6 February 2020 \\ (c) The Chinese Society for Metals (CSM) and Springer-Verlag GmbH Germany, part of Springer Nature 2020
}

\begin{abstract}
In this study, powder mixtures containing (Ti, W)C additions (10, 20, 30 and $40 \mathrm{wt} \%)$ were prepared and then consolidated at $1200,1250,1300$ and $1350{ }^{\circ} \mathrm{C}$ by spark plasma sintering. The effect of $(\mathrm{Ti}, \mathrm{W}) \mathrm{C}$ additions on the microstructure and mechanical properties of ultrafine WC-Co materials was investigated. The results demonstrate that the (Ti, W)C not only retards the sintering densification but also increases the porosity of sintered samples. The increasing sintering temperature is beneficial to the densification but results in the grain coarsening and the dissolution of $\mathrm{W}$ in $(\mathrm{Ti}, \mathrm{W}) \mathrm{C}$. Moreover, there are no $(\mathrm{Ti}, \mathrm{W}) \mathrm{C}$ grains with obvious core/rim structure in the microstructure. With the (Ti, W)C increasing from 10 to $20 \mathrm{wt} \%$, the hardness increases and fracture toughness changes hardly. However, the hardness and fracture toughness decrease slightly as the $(\mathrm{Ti}, \mathrm{W}) \mathrm{C}$ further increases. The transgranular fracture of $(\mathrm{Ti}, \mathrm{W}) \mathrm{C}$ phases is responsible for the slight reduction in fracture toughness. The sample with $20 \mathrm{wt} \%(\mathrm{Ti}, \mathrm{W}) \mathrm{C}$ has high hardness and fracture toughness $\left(H_{\mathrm{V}}: 21.3 \mathrm{GPa}, K_{\mathrm{IC}}: 9.8 \mathrm{MPa} \mathrm{m}^{1 / 2}\right)$.
\end{abstract}

Keywords $(\mathrm{Ti}, \mathrm{W}) \mathrm{C} \cdot$ Cemented carbides $\cdot$ Spark plasma sintering $\cdot$ Microstructure $\cdot$ Mechanical properties

\section{Introduction}

WC-Co cemented carbides have been more widely used for manufacturing cutting tools compared to other tool materials such as diamonds and ceramics due to their excellent comprehensive hardness and toughness [1,2]. It has been recognized that some carbide additives can improve the performance of WC-Co tool materials in machining of hard materials. $\mathrm{TaC}$ and $\mathrm{NbC}$ can not only increase hardness of WC-Co because of inhibiting the growth of WC grains, but improve the wear resistance due to its high resistance against the oxidation and diffusion wear [3]. An extensive combination of various microstructures and properties can be achieved by adjusting the sintering and treatment process, hard phase (WC and other carbides) and metal phase $[4,5]$.

Available online at http://link.springer.com/journal/40195.

Zhenhua Wang

niatwzh17@163.com

$\triangle$ Juntang Yuan

mc106@njust.edu.cn

1 School of Mechanical Engineering, Nanjing University of Science and Technology, Nanjing 210094, China
Some studies have reported that adding some cubic carbides ( $\mathrm{TiC}, \mathrm{TaC}, \mathrm{NbC})$ to $\mathrm{WC}-\mathrm{Co}$ brings out the $(\mathrm{M}, \mathrm{W}) \mathrm{C}$ $(\mathrm{M}=\mathrm{Ti} / \mathrm{Ta} / \mathrm{Nb})$ solid solution $[6,7]$. Gao et al. [8] reported that adding $\mathrm{NbC}$ in $\mathrm{WC}-\mathrm{Co}$ causes $\mathrm{W}$ dissolved into $\mathrm{NbC}$ grains to form $(\mathrm{Nb}, \mathrm{W}) \mathrm{C}$. TiC is a kind of stable carbide with higher hardness than WC. The addition of TiC effectively increases the hardness and improves wear resistance of WC-Co materials. However, it is easy to generate obvious core/rim structure in the microstructure after sintering. Yoon et al. [9] prepared 70(25TiC-75WC)-30Co cemented carbides by liquid-phase sintering. The results reveal that rounded $(\mathrm{Ti}, \mathrm{W}) \mathrm{C}$ grains with core/rim structure are produced in the microstructure, in which the core phase is TiC while the rim phase is $(\mathrm{Ti}, \mathrm{W}) \mathrm{C}$ solid solution. The dissolution of WC in TiC and the concentration gradient of WC are responsible for the formation of core/rim structure. Chen et al. [10] suggested that the core/rim structure is conducive to the crack propagation and leads to the significant decrease in strength and toughness. Gao et al. [11] fabricated WC-TiC-TaC-Ni cemented carbides by hot-pressed sintering and found that the fracture toughness decreases by about $40 \%$ when the $\mathrm{TiC}$ increases from 10 to $25 \mathrm{wt} \%$. In order to prevent the reduction in toughness caused by the core/rim structure, it is likely feasible to add homogeneous 
(Ti, W)C powder in $\mathrm{WC}-\mathrm{Co}$. The $(\mathrm{Ti}, \mathrm{W}) \mathrm{C}$ solid solution has better wettability with $\mathrm{Co}$ than $\mathrm{TiC}$, which improves the toughness of cemented carbides [12]. However, there are few reports about effects of $(\mathrm{Ti}, \mathrm{W}) \mathrm{C}$ on the microstructure and mechanical properties of WC-Co.

Compared to conventional sintering techniques, spark plasma sintering is characterized by the lower sintering temperature, faster heating rate and shorter sintering time [13-15]. These characteristics are beneficial to inhibit the grain growth, prepare ultrafine WC grains and improve properties of WC-Co [1]. Bonache et al. [16] prepared WC-12Co cemented carbides by spark plasma sintering and vacuum sintering. The results show that materials sintered by spark plasma sintering reach WC grain size values $70 \%$ smaller and achieve hardness values $20 \%$ higher than that sintered by vacuum sintering. Therefore, spark plasma sintering has quickly become popular to consolidate materials with fine grain sizes [17]. In the present work, homogeneous ( $\mathrm{Ti}, \mathrm{W})$ $\mathrm{C}$ powder was added for preparing $\mathrm{WC}-(\mathrm{Ti}, \mathrm{W}) \mathrm{C}-\mathrm{Co}$ tool materials by spark plasma sintering. The effects of (Ti, W) $\mathrm{C}$ addition on the microstructure and mechanical properties of ultrafine WC-Co were studied in detail.

\section{Experimental}

Raw materials used in this work were $\mathrm{WC},(\mathrm{Ti}, \mathrm{W}) \mathrm{C}, \mathrm{Co}, \mathrm{VC}$ and $\mathrm{Cr}_{3} \mathrm{C}_{2}$ powders, which were commercially purchased. $\mathrm{VC}$ and $\mathrm{Cr}_{3} \mathrm{C}_{2}$ powders were added as grain growth inhibitors. Average particle sizes of powders were measured by BET method and laser particle size analyzer (LPSA). Characteristics of $\mathrm{WC},(\mathrm{Ti}, \mathrm{W}) \mathrm{C}$ and Co powders are given in Table 1. Ti-to-W atomic ratio (at.\%) in the (Ti, W)C powder was 63:37. A mixture of starting powders was milled for $4 \mathrm{~h}$ in the planetary ball mill using pure ethanol as the liquid medium. Balls for ball milling were made by $\mathrm{WC}$, and their diameters were $6 \mathrm{~mm}$. The ball-to-powder ratio was 8:1, and the rotation speed was $250 \mathrm{r} / \mathrm{min}$. SEM images of starting powders and composite powders are shown in Fig. 1. As shown in Fig. 1d, WC powders exhibit the equiaxial shape and fine particle size. $(\mathrm{Ti}, \mathrm{W}) \mathrm{C}$ powders present the irregular shape and relatively large grain size. Some Co powders remain in the spherical shape after mixing.
Composite powders were consolidated by spark plasma sintering at $1200,1250,1300$ and $1350{ }^{\circ} \mathrm{C}$ with the holding time of $5 \mathrm{~min}$ and heating rate of $100{ }^{\circ} \mathrm{C} / \mathrm{min}$. The sintering pressure applied on the graphite die was $70 \mathrm{MPa}$ all the time during sintering. Dimensions of sintered samples were $15 \mathrm{~mm} \times 15 \mathrm{~mm} \times 5 \mathrm{~mm}$. Compositions and symbols of samples in this work are listed in Table 2. Phase constitution of samples was identified by X-ray diffraction (XRD) with copper $K \alpha$ radiation. Microstructure of samples was observed on the polished surface using the scanning electron microscope (SEM). Element distribution was investigated using the energy-dispersive spectrometer analysis system (SEM-EDS). Vickers hardness was measured using the hardness tester. The load and loading duration was $30 \mathrm{~kg}$ and $15 \mathrm{~s}$, respectively. Fracture toughness was calculated based on the cracks length generated by indentation [18].

\section{Results and Discussion}

\subsection{Densification Behavior and Microstructure}

Figure 2 shows shrinkage displacement and rate of composite powders with different $(\mathrm{Ti}, \mathrm{W}) \mathrm{C}$ contents. Obviously, (Ti, $\mathrm{W}) \mathrm{C}$ has a significant influence on the sintering shrinkage behavior of materials. As shown in Fig. 2a, the shrinkage displacement of TW10-40 is recorded as 2.68, 2.36, 2.03 and $1.69 \mathrm{~mm}$, respectively. The shrinkage displacement of materials decreases with the increasing $(\mathrm{Ti}, \mathrm{W}) \mathrm{C}$. A plausible explanation is that WC powder is compacted more compared to $(\mathrm{Ti}, \mathrm{W}) \mathrm{C}$ powder. For TW10, the shrinkage process starts at $750{ }^{\circ} \mathrm{C}$ and ends at $1200{ }^{\circ} \mathrm{C}$. With the $(\mathrm{Ti}$, $\mathrm{W}) \mathrm{C}$ increasing to $40 \mathrm{wt} \%$, the starting and ending shrinkage temperatures of TW 40 are postponed to $865^{\circ} \mathrm{C}$ and $1230{ }^{\circ} \mathrm{C}$, respectively. This demonstrates that the shrinkage process of materials is retarded and carried out in a high temperature range with the increasing $(\mathrm{Ti}, \mathrm{W}) \mathrm{C}$.

Figure $2 \mathrm{~b}$ shows that the shrinkage rate of materials decreases at low temperature with the increase in $(\mathrm{Ti}, \mathrm{W})$ C. The shrinkage rate of materials with high $(\mathrm{Ti}, \mathrm{W}) \mathrm{C}$ content increases slightly at the low temperature, while increases dramatically when the sintering temperature is higher than $1000{ }^{\circ} \mathrm{C}$. The early shrinkage of cemented

Table 1 Charactristics of WC, (Ti, W)C and Co raw powders

\begin{tabular}{lllllll}
\hline Powder & Purity $(\%)$ & Particle size, $d_{\text {LPSA }}$ & Particle size, $d_{\text {BET }}$ & C content $(w t \%)$ & O content (wt\%) & Manufacturer \\
\hline WC & $\geq 99.9$ & $60 \mathrm{~nm}$ & $38 \mathrm{~nm}$ & 6.13 & 0.09 & $\begin{array}{c}\text { Shanghai } \\
\text { ChaoWei-Nano } \\
\text { Co., Ltd }\end{array}$ \\
$(\mathrm{Ti}, \mathrm{W}) \mathrm{C}$ & $\geq 99.9$ & $1.5 \mu \mathrm{m}$ & & 5.19 & 0.08 \\
Co & $\geq 99.9$ & $500 \mathrm{~nm}$ & - & - & 0.09 & \\
\hline
\end{tabular}



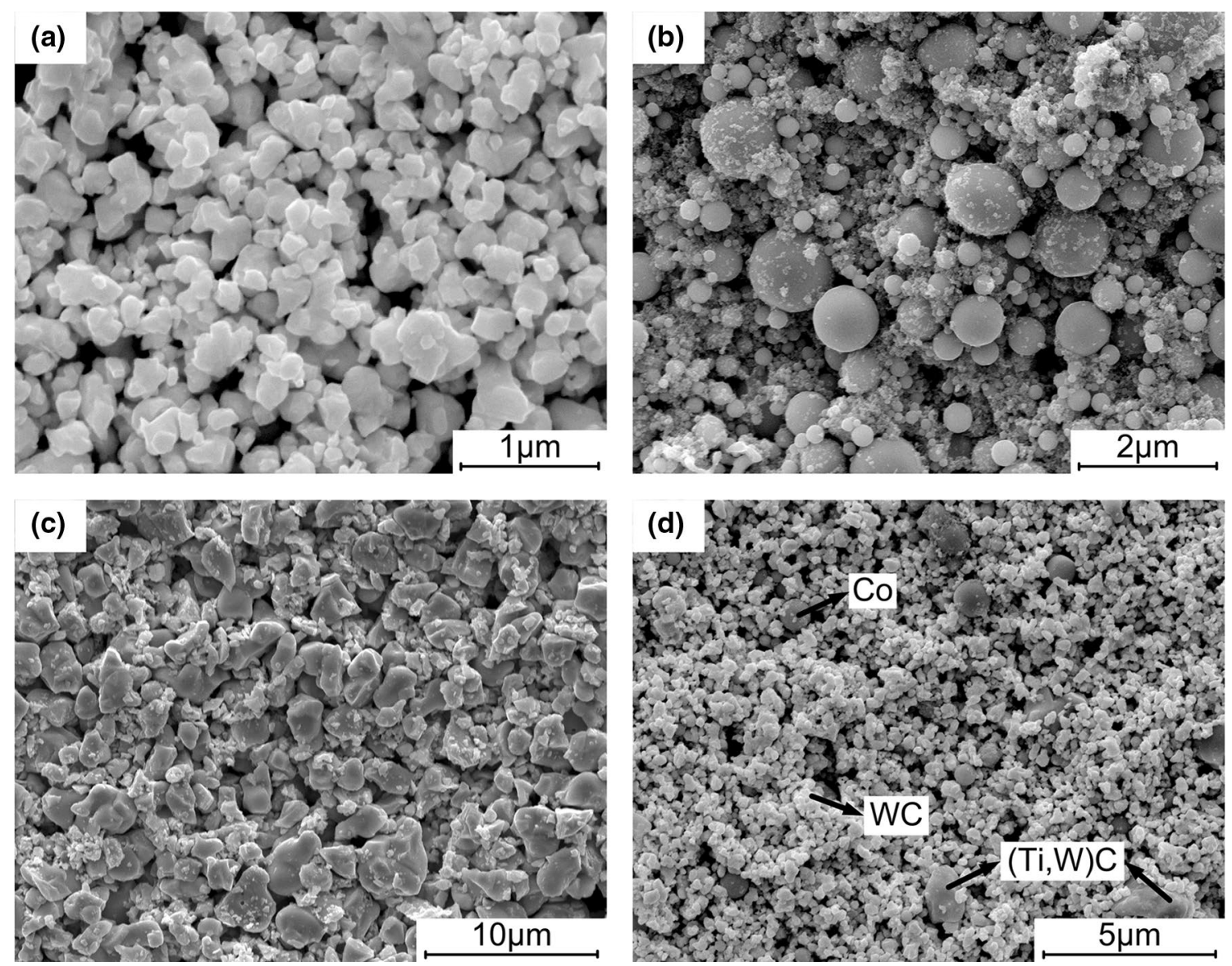

Fig. 1 SEM images showing morphologies of starting and composite powders: (a) WC, (b) Co, (c) (Ti, W)C, (d) WC-20(Ti, W)C-8Co

Table 2 Compositions and symbols of sintered samples (wt\%)

\begin{tabular}{lllllll}
\hline Cemented carbides & Symbol & WC & (Ti, W)C & Co & VC & Cr $_{3} \mathrm{C}_{2}$ \\
\hline WC-10(Ti, W)C-8Co & TW10 & Bal. & 10 & 8 & 0.4 & 0.4 \\
WC-20(Ti, W)C-8Co & TW20 & Bal. & 20 & 8 & 0.4 & 0.4 \\
WC-30(Ti, W)C-8Co & TW30 & Bal. & 30 & 8 & 0.4 & 0.4 \\
WC-40(Ti, W)C-8Co & TW40 & Bal. & 40 & 8 & 0.4 & 0.4 \\
\hline
\end{tabular}

carbides is controlled by Co binder diffusing over carbide surfaces [19]. Because nanosized WC powder is dominant in materials with low $(\mathrm{Ti}, \mathrm{W}) \mathrm{C}$ content and the fine WC and Co powders have high activity, the diffusion rate of materials is relatively high at low temperature. As the (Ti, W)C increases, Co binder spreading over ( $\mathrm{Ti}, \mathrm{W}) \mathrm{C}$ surfaces is prevented due to the poorer wetting for Co on $(\mathrm{Ti}, \mathrm{W}) \mathrm{C}$ than $\mathrm{WC}$, which affects the diffusion process at low temperature. Meanwhile, the increase in $(\mathrm{Ti}, \mathrm{W}) \mathrm{C}$ impedes the dissolution of $\mathrm{WC}$ in Co. As a result, at low temperature, the diffusion rate is relatively low for materials with high $(\mathrm{Ti}, \mathrm{W}) \mathrm{C}$ content. As the $(\mathrm{Ti}, \mathrm{W}) \mathrm{C}$ increases, materials lack the slow shrinkage stage characterized by surface diffusion.
Figure 3 shows the volumetric shrinkage of WC-(Ti, W) $\mathrm{C}-\mathrm{Co}$ cemented carbides after sintering. The volumetric shrinkage of samples decreases gradually with the increasing $(\mathrm{Ti}, \mathrm{W}) \mathrm{C}$, which is consistent with results in Fig. 2a. The volumetric shrinkage of TW10 reaches $48.5 \%$ at $1250{ }^{\circ} \mathrm{C}$ and does not increase obviously as the sintering temperature further increases. However, for TW30 and TW40, the volumetric shrinkage does not reach to the maximum at $1250{ }^{\circ} \mathrm{C}$ and still presents an increasing trend as the temperature increases to $1350^{\circ} \mathrm{C}$.

Figure 4 shows microstructures of WC-(Ti, W)C-Co cemented carbides sintered at 1250 and $1350{ }^{\circ} \mathrm{C}$. Bright and gray areas represent the $\mathrm{WC}$ and $(\mathrm{Ti}, \mathrm{W}) \mathrm{C}$ phases, respectively. From Fig. 4, some pores are observed in the 

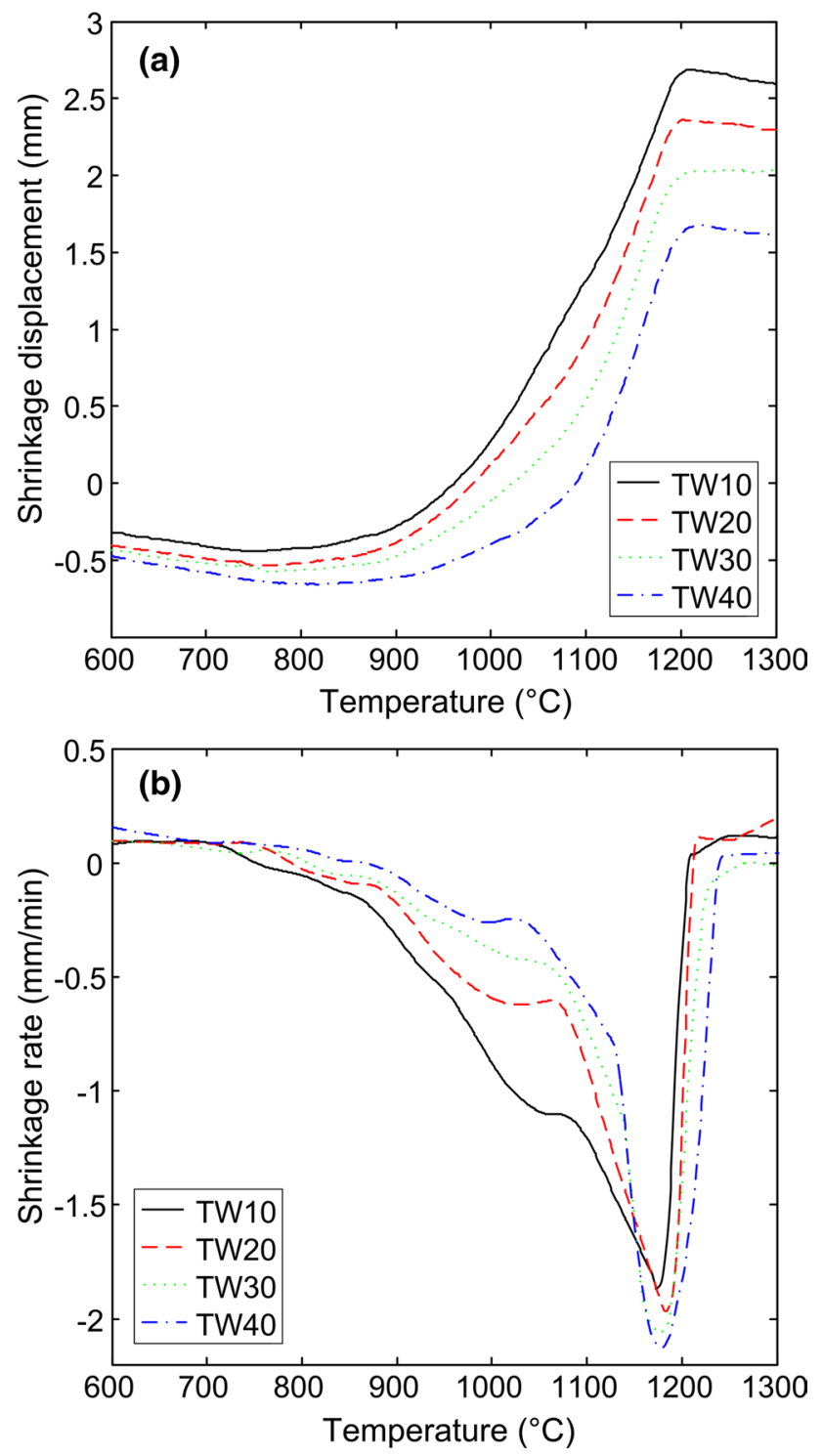

Fig. 2 Shrinkage behavior of composite powders with different (Ti, W)C contents: (a) shrinkage displacement, (b) shrinkage rate

microstructure of samples. At $1250{ }^{\circ} \mathrm{C}$, samples with higher (Ti, W)C content exhibit higher levels of porosity, as shown in Fig. 4e, g. Apparently, at $1250{ }^{\circ} \mathrm{C}$, the densification of $\mathrm{WC}-(\mathrm{Ti}, \mathrm{W}) \mathrm{C}-\mathrm{Co}$ is deteriorated with the increasing ( $\mathrm{Ti}$, W)C.

Generally, the densification and shrinkage of samples at high temperature can be attributed to the formation of liquid Co phases. During the liquid-phase sintering, the particle rearrangement and dissolution-precipitation make carbide particles move closer to each other, which results in the dense microstructure and increases volumetric shrinkage of samples. Fine WC particles have high interfacial energy due to the high surface-to-volume ratio and the large volume fraction of grain boundary, which provides

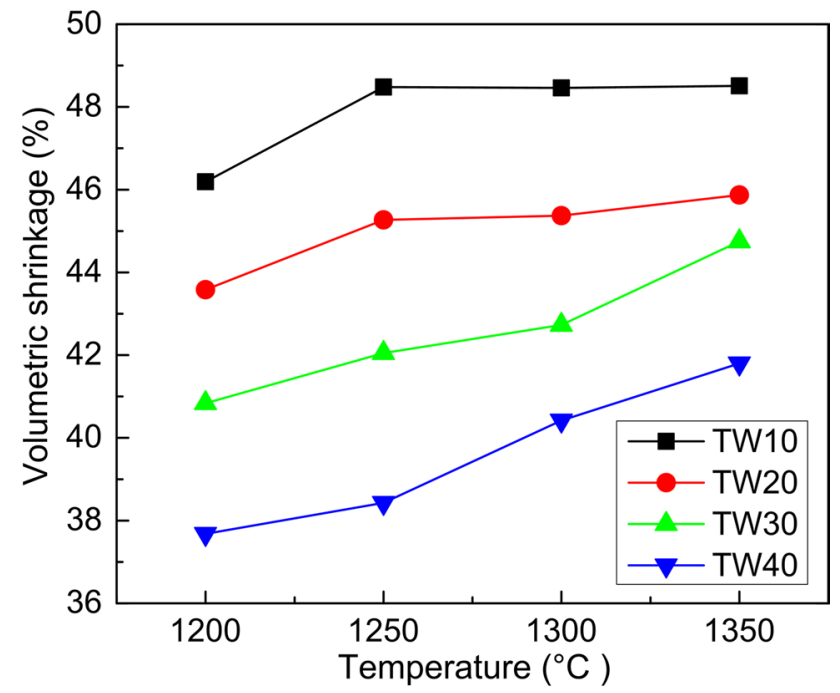

Fig. 3 Volumetric shrinkage of WC-(Ti, W)C-Co sintered at different temperatures

the strong driving force for diffusion and causes liquid phases to appear at the lower temperature [20]. Because nanosized WC powder is dominant for samples with low (Ti, W)C content, it is reasonable to suggest that TW10 has the high solid-phase diffusion rate and good liquidphase sintering effect at low sintering temperatures. Therefore, at $1250{ }^{\circ} \mathrm{C}$, TW 10 achieves a relatively high volumetric shrinkage (Fig. 3) and presents a dense microstructure (Fig. 4a). However, the increasing (Ti, W)C hinders the diffusion of Co binder and increases the temperature of liquid-phase sintering. At $1250{ }^{\circ} \mathrm{C}$, for samples with high (Ti, W)C content, liquid phases cannot completely fill in spaces formed by carbides, which leads to the formation of pores, as shown in Fig. 4e, g. Moreover, because the condition for Co wetting on $(\mathrm{Ti}, \mathrm{W}) \mathrm{C}$ is poorer than on $\mathrm{WC}$, there is lower capillary force for liquid phases in particles, causing that particles cannot rearrange densely. As a result, pores mainly appear near $(\mathrm{Ti}, \mathrm{W}) \mathrm{C}$ phases. Similarly, Ref. [21] also indicated that second phase additions suppress $\mathrm{W}$ skeleton densification, which is related to the lower surface diffusion and changing wettability.

As the temperature increases to $1350{ }^{\circ} \mathrm{C}$, pores reduce obviously in the microstructure, as shown in Fig. 4b, d, f, $\mathrm{h}$. More liquid phases and thermal energies are produced with the increase in temperature. The increasing liquid

Fig. 4 SEM images showing microstructures of WC-(Ti, W)C-Co: (a) TW10 sintered at $1250{ }^{\circ} \mathrm{C}$, (b) TW10 sintered at $1350{ }^{\circ} \mathrm{C}$, (c) TW20 sintered at $1250{ }^{\circ} \mathrm{C}$, (d) TW20 sintered at $1350{ }^{\circ} \mathrm{C}$, (e) TW30 sintered at $1250{ }^{\circ} \mathrm{C}$, (f) $\mathrm{TW} 30$ sintered at $1350{ }^{\circ} \mathrm{C}$, (g) TW40 sintered at $1250{ }^{\circ} \mathrm{C}$, (h) $\mathrm{TW} 40$ sintered at $1350{ }^{\circ} \mathrm{C}$ 

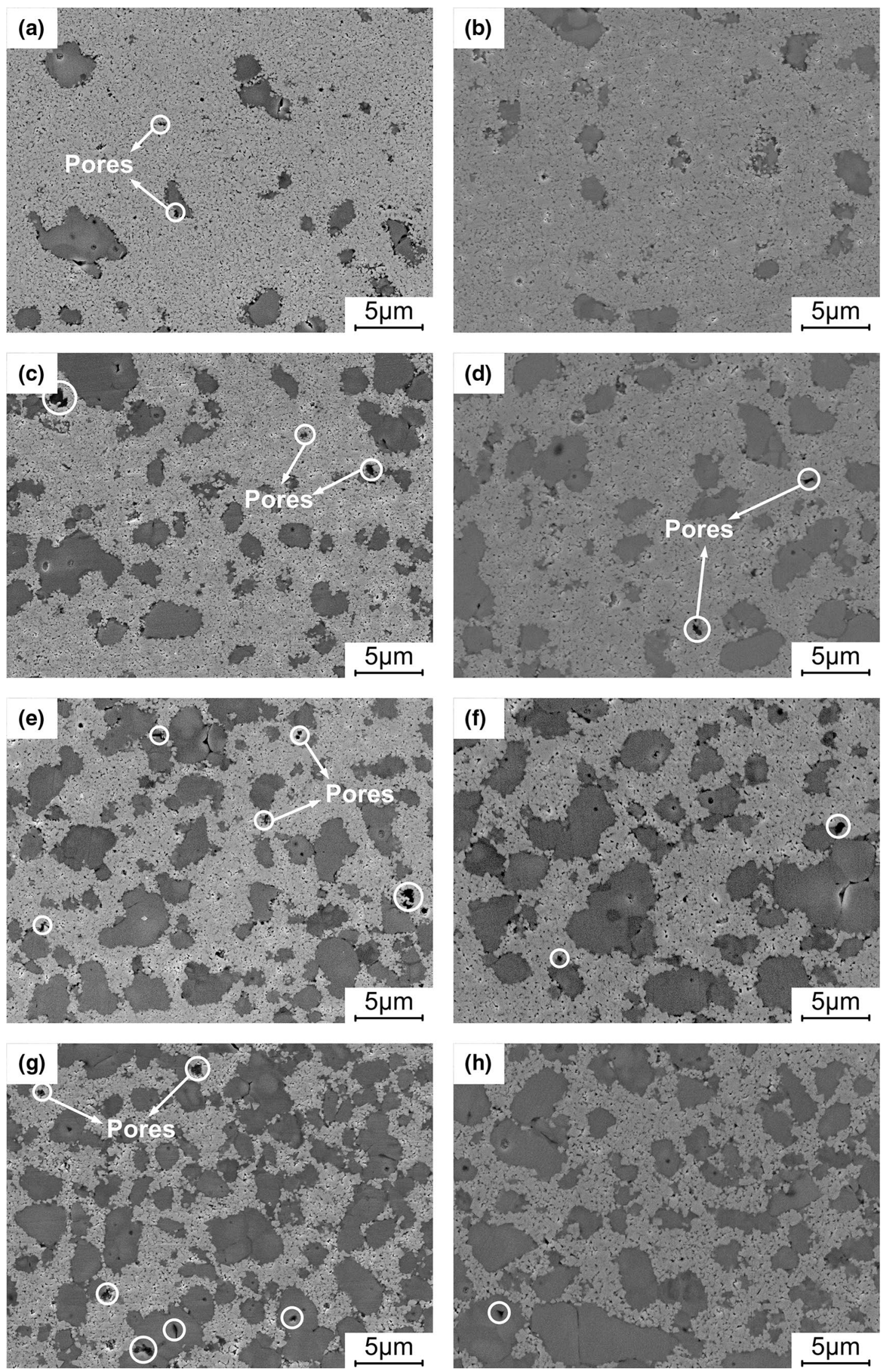

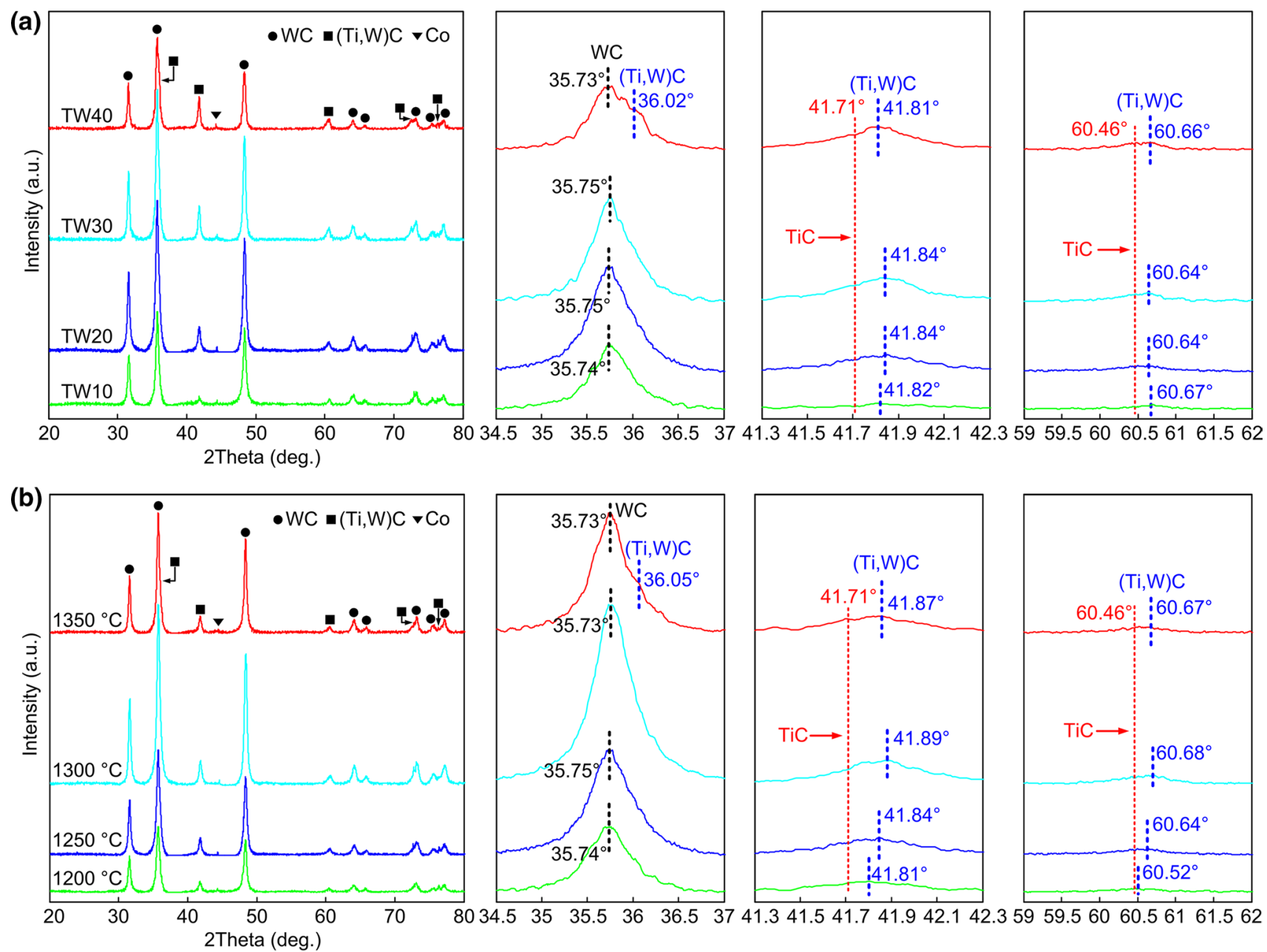

Fig. 5 XRD patterns of (a) samples TW10, TW20, TW30 and TW40 sintered at $1250{ }^{\circ} \mathrm{C}$, (b) sample TW20 sintered at $1200{ }^{\circ} \mathrm{C}, 1250{ }^{\circ} \mathrm{C}$, $1300{ }^{\circ} \mathrm{C}$ and $1350{ }^{\circ} \mathrm{C}$

phases promote the dissolution-precipitation and fill in pores sufficiently, which produces good liquid-phase sintering results. Meanwhile, the flow resistance of carbide particles decreases, causing the carbide particles to arrange densely. Therefore, at $1350{ }^{\circ} \mathrm{C}$, for samples with high $(\mathrm{Ti}, \mathrm{W}) \mathrm{C}$ content, pores decrease and the volumetric shrinkage increases, as shown Figs. 3, 4f, h.

\subsection{Phase Constitution}

Figure 5 shows XRD patterns of sintered WC-(Ti, W)C-Co cemented carbides. There are no changes in phases as the sintering temperature and $(\mathrm{Ti}, \mathrm{W}) \mathrm{C}$ increase. No cobalt or tungsten compounds are found except $\mathrm{WC},(\mathrm{Ti}, \mathrm{W}) \mathrm{C}$ and $\mathrm{Co}$ phases. Graphite and $\eta$ phases are not produced in all samples during sintering process. It is well known that $(\mathrm{Ti}, \mathrm{W})$ $\mathrm{C}$ has the same $\mathrm{B} 1(\mathrm{NaCl})$ crystal structure as TiC. Because the atomic radius of $\mathrm{W}$ is less than that of $\mathrm{Ti}$, diffraction angles of $(\mathrm{Ti}, \mathrm{W}) \mathrm{C}$ are slightly larger than that of TiC. As shown in Fig. 4a, with the increase in (Ti, W)C, diffraction peaks of $(\mathrm{Ti}, \mathrm{W}) \mathrm{C}$ become stronger while peak positions shift barely. As shown in Fig. 4b, diffraction peaks of (Ti, $\mathrm{W}) \mathrm{C}$ phases tend to move slightly toward high angles as the temperature increases from 1200 to $1350{ }^{\circ} \mathrm{C}$. Two peak positions of ( $\mathrm{Ti}, \mathrm{W}) \mathrm{C}$ phases shift from 41.81 to 41.87 and from 60.52 to 60.67 . This is likely attributed to the fact that $\mathrm{W}$ atoms further dissolve in the $(\mathrm{Ti}, \mathrm{W}) \mathrm{C}$ with the increase of temperature.

Figure 6 shows SEM images and EDS line analysis results of $(\mathrm{Ti}, \mathrm{W}) \mathrm{C}$ grains in TW20 sintered at 1250 and $1350{ }^{\circ} \mathrm{C}$. From Fig. 6a, it is found that $\mathrm{Ti}, \mathrm{W}$ and $\mathrm{C}$ are distributed uniformly in $(\mathrm{Ti}, \mathrm{W}) \mathrm{C}$ grains, and there are no changes for $\mathrm{Ti}$ and $\mathrm{W}$ contents from point $\mathrm{B}$ to $\mathrm{C}$. However, at $1350^{\circ} \mathrm{C}$, the $\mathrm{W}$ content decreases while $\mathrm{Ti}$ content increases from the rim to core of $(\mathrm{Ti}, \mathrm{W}) \mathrm{C}$ grains, as shown in Fig. 6b. This indicates that the $\mathrm{W}$ content of $(\mathrm{Ti}, \mathrm{W}) \mathrm{C}$ rim is higher than that of core ( $\mathrm{Ti}$ content of $(\mathrm{Ti}, \mathrm{W}) \mathrm{C}$ rim is lower than that of core). 

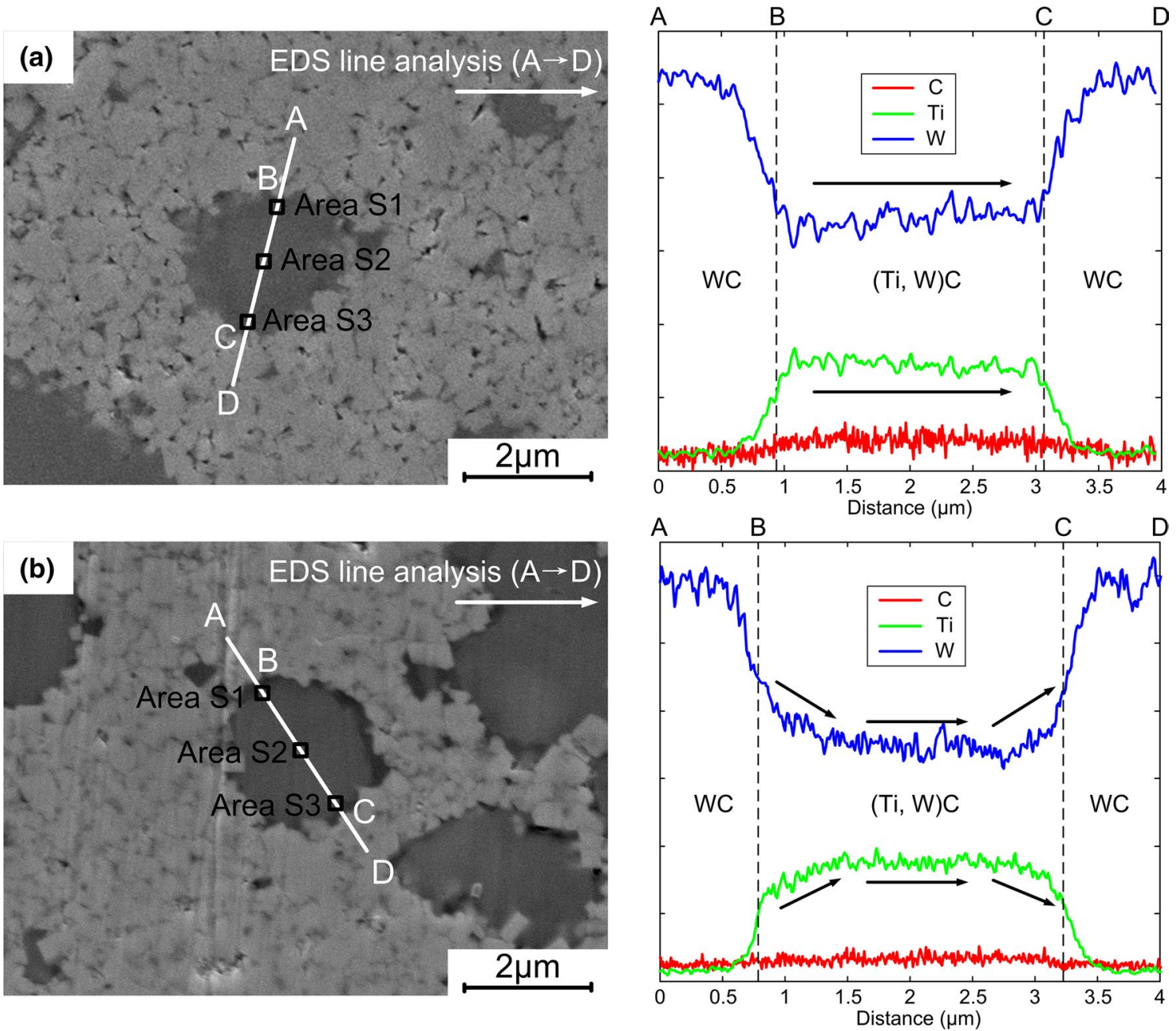

Fig. 6 SEM images and EDS line analyses of (Ti, W)C grain in sample TW20 sintered at (a) $1250{ }^{\circ} \mathrm{C}$ and (b) $1350{ }^{\circ} \mathrm{C}$

The SEM-EDS results of $(\mathrm{Ti}, \mathrm{W}) \mathrm{C}$ rim and core (areas $\mathrm{S} 1, \mathrm{~S} 2$ and S3 in Fig. 6) are given in Table 3. At $1250{ }^{\circ} \mathrm{C}$, the Ti-to-W ratio of $(\mathrm{Ti}, \mathrm{W}) \mathrm{C}$ rim is similar to that of core. The Ti-to-W ratio of areas S1, S2 and S3 is 61:39, 59:41 and $62: 38$, respectively. Since the dissolution of $\mathrm{W}$ in $(\mathrm{Ti}, \mathrm{W}) \mathrm{C}$ is limited by low sintering temperature, the Ti-to-W ratio in $(\mathrm{Ti}, \mathrm{W}) \mathrm{C}$ grains is similar to that in $(\mathrm{Ti}, \mathrm{W}) \mathrm{C}$ powder. At $1350{ }^{\circ} \mathrm{C}$, the Ti-to-W ratio of $(\mathrm{Ti}, \mathrm{W}) \mathrm{C}$ rim and core is 52:48 and 64:36, respectively. According to EDS results, it is found that the $\mathrm{W}$ content of $(\mathrm{Ti}, \mathrm{W}) \mathrm{C}$ rim increases as the temperature increases. Therefore, $\mathrm{W}$ atoms can further dissolve in the $(\mathrm{Ti}, \mathrm{W}) \mathrm{C}$ at high sintering temperature, which is consistent with XRD results. Because there are few differences for Ti-to- $\mathrm{W}$ ratio between the core and rim even if at $1350{ }^{\circ} \mathrm{C},(\mathrm{Ti}, \mathrm{W}) \mathrm{C}$ grains do not exhibit obvious core/ rim structure. Compared to the obvious core/rim structure in which core is rich $\mathrm{TiC}$ phases and rim is $(\mathrm{Ti}, \mathrm{W}) \mathrm{C}$ phase, the uniform $(\mathrm{Ti}, \mathrm{W}) \mathrm{C}$ structure avoids the lattice parameter
Table 3 SEM-EDS results of $(\mathrm{Ti}, \mathrm{W}) \mathrm{C}$ grains in sample TW20

\begin{tabular}{|c|c|c|c|c|c|c|c|c|c|}
\hline \multirow[t]{2}{*}{ Area-No } & & \multicolumn{4}{|c|}{$1250^{\circ} \mathrm{C}$} & \multicolumn{4}{|c|}{$1350^{\circ} \mathrm{C}$} \\
\hline & & $\mathrm{C}$ & $\mathrm{Ti}$ & W & Ti-to-W ratio & $\mathrm{C}$ & $\mathrm{Ti}$ & W & Ti-to-W ratio \\
\hline \multirow[t]{2}{*}{ S1 (rim) } & at. $\%$ & 59.45 & 24.74 & 15.81 & $61: 39$ & 55.20 & 23.16 & 21.64 & $52: 48$ \\
\hline & $\mathrm{wt} \%$ & 14.86 & 24.65 & 60.49 & & 11.53 & 19.26 & 69.18 & \\
\hline \multirow[t]{2}{*}{ S2 (core) } & at. $\%$ & 58.71 & 24.36 & 16.93 & $59: 41$ & 54.73 & 28.99 & 16.28 & $64: 36$ \\
\hline & $\mathrm{wt} \%$ & 14.15 & 23.40 & 62.45 & & 13.05 & 27.56 & 59.39 & \\
\hline \multirow[t]{2}{*}{ S3 (rim) } & at. $\%$ & 60.35 & 24.58 & 15.07 & $62: 38$ & 55.35 & 23.41 & 21.24 & $52: 48$ \\
\hline & $\mathrm{wt} \%$ & 15.52 & 25.18 & 59.30 & & 11.68 & 19.71 & 68.61 & \\
\hline
\end{tabular}



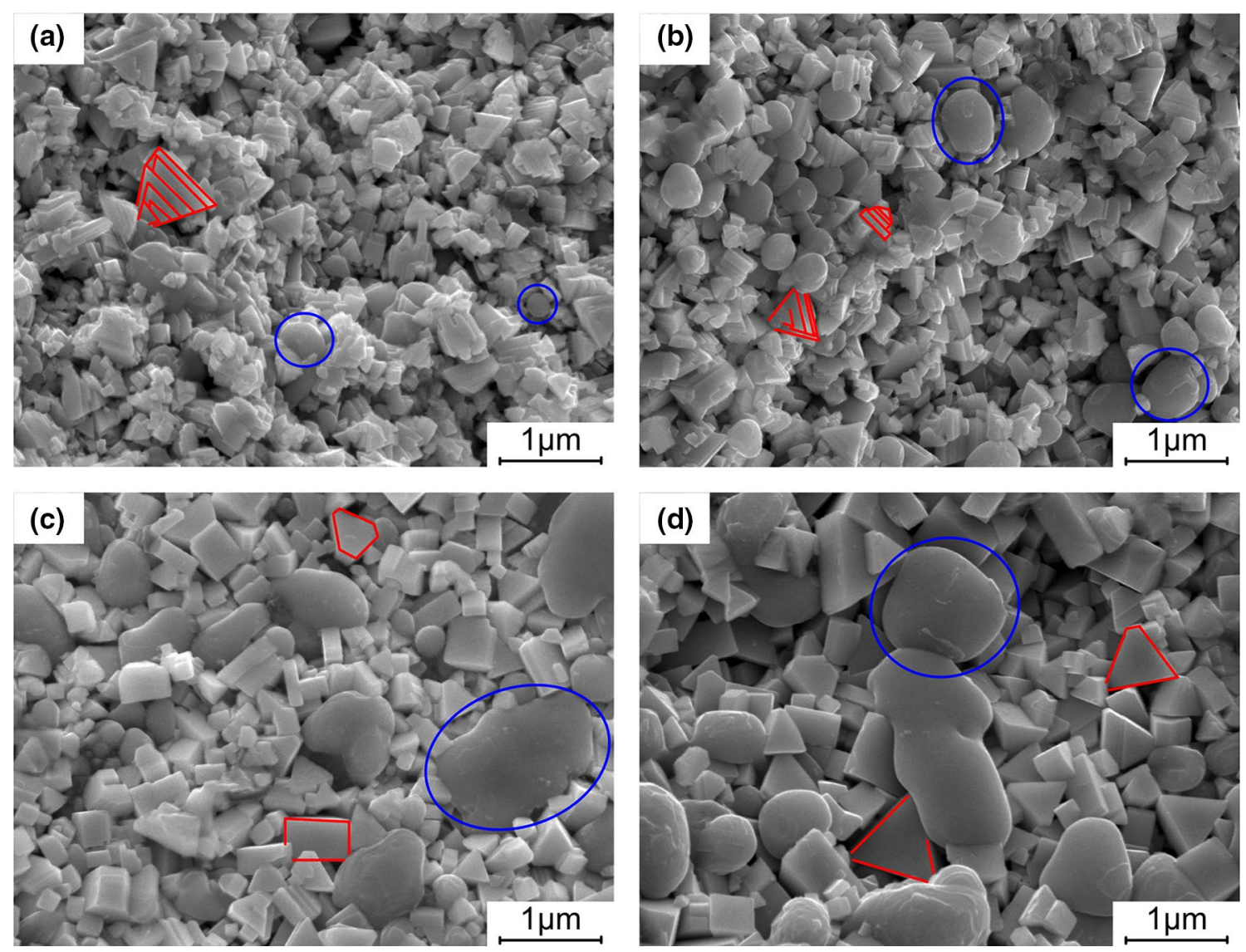

Fig. 7 SEM images showing grain morphologies of sample TW20 sintered at (a) $1200^{\circ} \mathrm{C}$, , (b) $1250{ }^{\circ} \mathrm{C},(\mathbf{c}) 1300^{\circ} \mathrm{C},(\mathbf{d}) 1350{ }^{\circ} \mathrm{C}$

difference between core and rim and prevents the generation of the strain and residual stress at core/rim interfaces [10]. Moreover, the uniform $(\mathrm{Ti}, \mathrm{W}) \mathrm{C}$ structure likely prevents the significant reduction of toughness caused by the presence of rich $\mathrm{TiC}$ phases in the microstructure.

\subsection{Grain Morphology and Growth}

Figure 7 shows $\mathrm{WC}$ and $(\mathrm{Ti}, \mathrm{W}) \mathrm{C}$ grain morphologies in WC-(Ti, W)C-Co cemented carbides. WC grains present prismatic shapes, and $(\mathrm{Ti}, \mathrm{W}) \mathrm{C}$ grains exhibit round shapes (shown by lines in Fig. 7). At 1200 and $1250{ }^{\circ} \mathrm{C}$, WC grains show multi-step structures due to $\mathrm{VC}$ and $\mathrm{Cr}_{3} \mathrm{C}_{2}$ additions. $\mathrm{VC}$ and $\mathrm{Cr}_{3} \mathrm{C}_{2}$ additions cause the $(\mathrm{W}, \mathrm{V}, \mathrm{Cr}) \mathrm{C}_{x}$ layers to form on the surface of WC grains [7, 22, 23], which hinders diffusion of $\mathrm{W}$ and $\mathrm{C}$ atoms and enhances energy barrier for nucleation. The new nucleus and preceding nucleuses grow simultaneously on WC basal planes, causing WC grains to stack on basal planes and to form multi-step structures. As a result, the WC grain growth is inhibited during the formation of multi-step structures. The increasing temperature enhances the solubility of WC in binder phases and the supplies of $\mathrm{W}$ and $\mathrm{C}$ atoms. Meanwhile, liquid phases
Co provide fast diffusion paths for $\mathrm{W}$ and $\mathrm{C}$ atoms, which enhances atomic diffusion and dissolution-precipitation rates. As a result, at 1300 and $1350{ }^{\circ} \mathrm{C}$, multi-step structures of WC grains disappear gradually and transform to prismatic shapes. Additionally, there are obvious grain growth and coarsening for WC grains.

The growth of rounded $(\mathrm{Ti}, \mathrm{W}) \mathrm{C}$ grains is still controlled by dissolution-precipitation mechanism (Ostwald ripening) $[24,25]$. The results of Ref. [9] indicated that the (Ti, W)C growth is governed by the atom diffusion through the liquid Co phases and also suggested that the effect of $(\mathrm{Ti}, \mathrm{W}) \mathrm{C}$ core on growth kinetics is inappreciable, i.e., the growth is largely determined by the precipitation of $(\mathrm{Ti}, \mathrm{W}) \mathrm{C}$ rim. It is found from Fig. 6 that the $\mathrm{W}$ content of rim phases increases while that of core phases remains unchanged with the increase of temperature. It is reasonable to suggest that partial WC and $(\mathrm{Ti}, \mathrm{W}) \mathrm{C}$ firstly dissolve in the liquid Co phases and then precipitate at the surface of undissolved $(\mathrm{Ti}, \mathrm{W}) \mathrm{C}$ through diffusion in the liquid matrix, resulting in the increase of $\mathrm{W}$ content and the growth of (Ti, W)C rim. Therefore, the (Ti, $\mathrm{W}) \mathrm{C}$ grain growth largely depends on the precipitation on the surface of undissolved $(\mathrm{Ti}, \mathrm{W}) \mathrm{C}$ grains, and the growth phase is $(\mathrm{Ti}, \mathrm{W}) \mathrm{C}$ rim. 

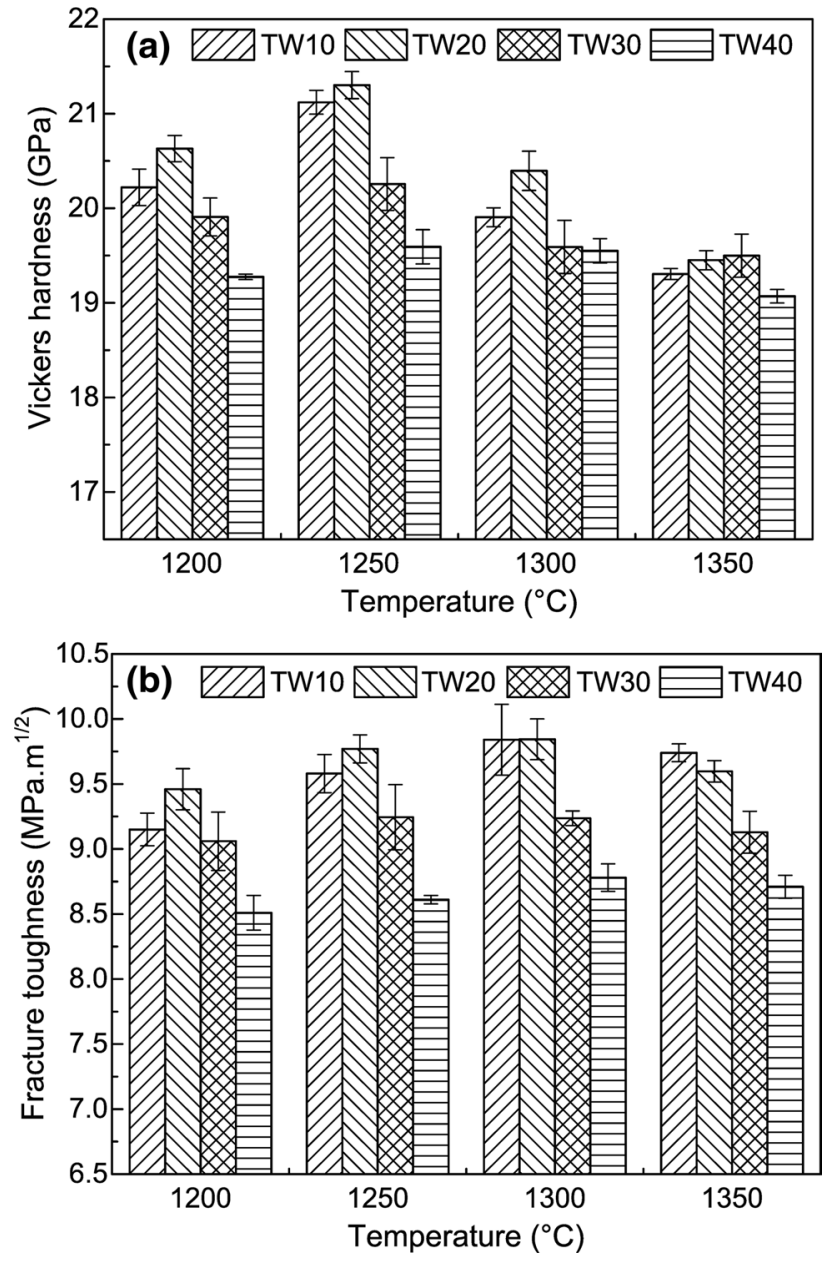

Fig. 8 (a) Hardness, (b) fracture toughness of WC-(Ti, W)C-Co with different $(\mathrm{Ti}, \mathrm{W}) \mathrm{C}$ contents

\subsection{Mechanical Properties}

Figure 8 shows hardness and fracture toughness of WC-(Ti, $\mathrm{W}) \mathrm{C}-\mathrm{Co}$ cemented carbides. With the $(\mathrm{Ti}, \mathrm{W}) \mathrm{C}$ increasing from 10 to $20 \mathrm{wt} \%$, the hardness increases and fracture toughness exhibits few changes. However, with the further addition of $(\mathrm{Ti}, \mathrm{W}) \mathrm{C}$, the hardness and fracture toughness present a slight downward trend. Obviously, at $1250^{\circ} \mathrm{C}$, the maximum hardness and fracture toughness are achieved by adding $20 \mathrm{wt} \%$ (Ti, W)C and are $21.3 \mathrm{GPa}$ and $9.8 \mathrm{MPa} \mathrm{m}^{1 / 2}$, respectively.

Second-phase particle, densification and grain size are important factors affecting the hardness of alloys [26-28]. The (Ti, W)C addition (20 wt\%) leads to higher hardness because $(\mathrm{Ti}, \mathrm{W}) \mathrm{C}$ phases have more hardness than WC phases [4]. However, as the ( $\mathrm{Ti}, \mathrm{W}) \mathrm{C}$ increases to 30 and $40 \mathrm{wt} \%$, the hardness of samples do not increase further. From results in Sect. 3.1, it is clear that some pores appear in the TW30 and TW40. The existence of pores is responsible for the slight decrease in hardness. Moreover, the sintering temperature has effects on the densification and grain size in some degrees, which further affects the hardness of cemented carbides. The hardness first increases and then decreases as the temperature increases, as shown in Fig. 8a. The densification of samples increases with the increasing temperature, resulting in the increase of hardness. As the temperature increases to 1300 and $1350{ }^{\circ} \mathrm{C}$, the grain coarsening phenomenon is clearly seen from the analysis in Fig. 7. Therefore, it is concluded that the grain growth causes the hardness to decrease (Hall-Petch relation).

Figure 9 shows crack propagation of $\mathrm{WC}-(\mathrm{Ti}, \mathrm{W}) \mathrm{C}-\mathrm{Co}$ cemented carbides sintered at $1250{ }^{\circ} \mathrm{C}$. For TW10, cracks mainly extend along grain boundaries of WC. It is well known that cracks mainly propagate along $\mathrm{WC} / \mathrm{WC}$ and $\mathrm{WC} /$ Co in ultrafine WC-Co because the fracture energy for transgranular fracture is higher than that of intergranular fracture $[8,29]$. It is difficult to observe the cracks passing through (Ti, W)C phases due to the low (Ti, W)C content, as shown in Fig. 9a. With the increase in $(\mathrm{Ti}, \mathrm{W}) \mathrm{C}$, the probability of crack passing through $(\mathrm{Ti}, \mathrm{W}) \mathrm{C}$ phase increases gradually, as shown in Fig. 9b-d. Because (Ti, W)C phases have higher brittleness compared to WC phases, cracks do not continue to extend along grain boundaries but pass through (Ti, W)C grains when cracks propagate to them. Therefore, the increasing $(\mathrm{Ti}, \mathrm{W}) \mathrm{C}$ phases make the resistance reduce against crack propagation, which limits the contribution of crack propagation in binder phases to the toughening. According to above discussion and results in Fig. 8b, it can be concluded that the transgranular fracture of $(\mathrm{Ti}, \mathrm{W}) \mathrm{C}$ increases with the increase in $(\mathrm{Ti}, \mathrm{W}) \mathrm{C}$, resulting in the slight decrease of fracture toughness.

Mechanical properties of other ultrafine cemented carbides are listed in Table 4. Compared to cemented carbides with TiC, TW20 has both higher hardness and fracture toughness. In addition, the hardness of TW20 is 10.8-31.9\% larger than that of cemented carbides without additives, while fracture toughness decreases few (only 0-9.2\%). In this study, $(\mathrm{Ti}, \mathrm{W}) \mathrm{C}$ not only increases the hardness effectively, but also reduces the loss of fracture toughness.

\section{Conclusions}

In the present work, the microstructure and mechanical properties of spark plasma-sintered WC-(Ti, W)C-Co tool materials were studied. Main conclusions were drawn as follow:

1. The shrinkage process of materials are retarded with (Ti, $\mathrm{W}) \mathrm{C}$ additions, and the volumetric shrinkage decreases gradually with the increasing $(\mathrm{Ti}, \mathrm{W}) \mathrm{C}$. It can be con- 

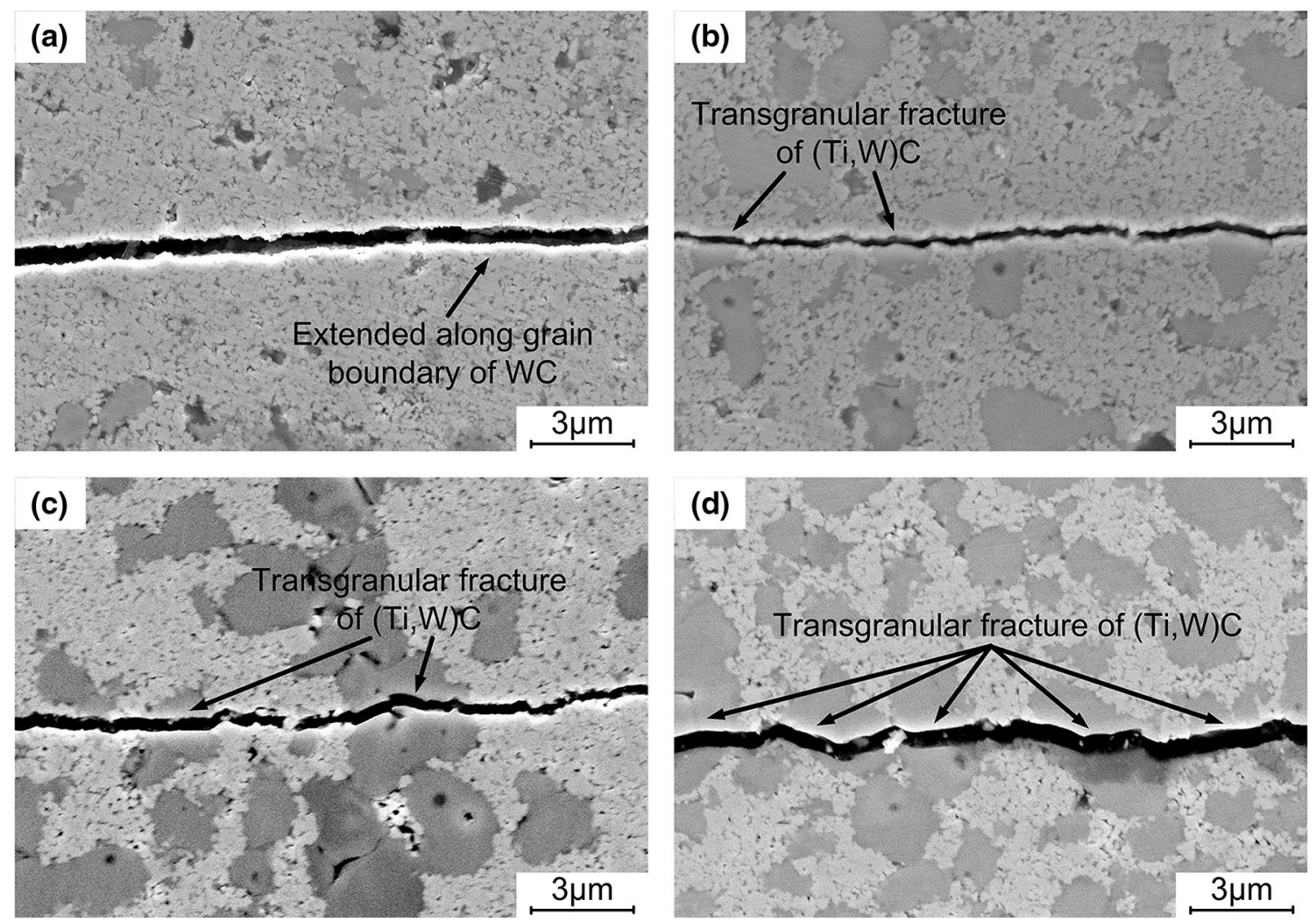

Fig. 9 SEM images showing crack propagation morphologies of WC-(Ti, W)C-Co sintered at $1250{ }^{\circ} \mathrm{C}$ : (a) TW10, (b) TW20, (c) TW30, (d) TW40

cluded that increasing $(\mathrm{Ti}, \mathrm{W}) \mathrm{C}$ has a negative effect on the densification process of $\mathrm{WC}-(\mathrm{Ti}, \mathrm{W}) \mathrm{C}-\mathrm{Co}$ materials.

2. At $1250{ }^{\circ} \mathrm{C}$, the pores of cemented carbides increase with the increase in $(\mathrm{Ti}, \mathrm{W}) \mathrm{C}$. For the sample with high ( $\mathrm{Ti}, \mathrm{W}) \mathrm{C}$ content, the increasing temperature reduces porosity and is conducive to the densification of microstructure. At $1350{ }^{\circ} \mathrm{C}, \mathrm{W}$ atoms further dissolve in $(\mathrm{Ti}$,
$\mathrm{W}) \mathrm{C}$, causing the $\mathrm{W}$ content of $(\mathrm{Ti}, \mathrm{W}) \mathrm{C}$ rim to increase. Moreover, high sintering temperature causes grain structure evolution and grain coarsening.

3. When ( $\mathrm{Ti}, \mathrm{W}) \mathrm{C}$ addition is $20 \mathrm{wt} \%$, the hardness and fracture toughness is $21.3 \mathrm{GPa}$ and $9.8 \mathrm{MPa} \mathrm{m}^{1 / 2}$, respectively. However, the hardness and fracture toughness decreases slightly with the further addition of (Ti,
Table 4 Mechanical properties of some ultrafine cemented carbides

\begin{tabular}{lllll}
\hline TiC additions (wt\%) & $\begin{array}{l}\text { Binder phases } \\
(\mathrm{wt} \%)\end{array}$ & Hardness $(\mathrm{GPa})$ & $K_{\mathrm{IC}}\left(\mathrm{MPa} \mathrm{m}^{1 / 2}\right)$ & Sintering technology \\
\hline $16 \mathrm{TiC}[30]$ & $6 \mathrm{Co}$ & 20.2 & - & Vacuum sintering \\
$5 \mathrm{TiC}[31]$ & $6 \mathrm{Co}$ & 19.8 & 10.1 & Hot pressing sintering \\
$25 \mathrm{TiC}[11]$ & $10 \mathrm{Ni}$ & 19.5 & 8.3 & Vacuum sintering \\
{$[17]$} & $8 \mathrm{Co}$ & 18.9 & 9.8 & Rapid omni compaction \\
{$[1]$} & $8 \mathrm{Co}$ & 16.2 & 9.6 & - \\
{$[1]$} & $8 \mathrm{Co}$ & 14.5 & 10.8 & - \\
{$[18]$} & $8 \mathrm{Co}$ & 19.0 & 9.6 & - \\
{$[16]$} & $12 \mathrm{Co}$ & 18.0 & 10.6 & Spark plasma sintering \\
{$[13]$} & $12 \mathrm{Co}$ & 18.9 & 10.2 & Spark plasma sintering \\
{$[16]$} & $12 \mathrm{Co}$ & 18.3 & 10.5 & Hot isostatic pressing \\
$20(\mathrm{Ti}, \mathrm{W}) \mathrm{C}^{\mathrm{a}}$ & $8 \mathrm{Co}$ & 21.3 & 9.8 & Spark plasma sintering \\
\hline
\end{tabular}

${ }^{\mathrm{a}} \mathrm{TW} 20$ in this study 
W)C. ( $\mathrm{Ti}, \mathrm{W}) \mathrm{C}$ phases make the resistance decrease against crack propagation due to their higher brittleness, resulting in the slight decrease of fracture toughness.

Acknowledgements This work was financially supported by the National Natural Science Foundation of China (Nos. 51775280 and 51675285) and the Six Talent Peaks Project in Jiangsu Province (No. 2016-HKHT-019).

\section{References}

[1] S. Farag, I. Konyashin, B. Ries, Int. J. Refract. Met. Hard Mater. 77, 12 (2018)

[2] S. Norgren, J. García, A. Blomqvist, L. Yin, Int. J. Refract. Met. Hard Mater. 48, 31 (2015)

[3] R. Merwe, N. Sacks, Int. J. Refract. Met. Hard Mater. 41, 94 (2013)

[4] J. Garcia, V.C. Ciprés, A. Blomqvist, B. Kaplan, Int. J. Refract. Met. Hard Mater. 80, 40 (2019)

[5] H.J. Zhang, L.Q. Chen, J. Sun, W.G. Wang, Q.Z. Wang, Acta Metall. Sin. (Engl. Lett.) 27, 894 (2014)

[6] A.S. Namini, Z. Ahmadi, A. Babapoor, M. Shokouhimehr, M.S. Asl, Ceram. Int. 45, 2153 (2019)

[7] X.W. Liu, X.Y. Song, H.B. Wang, M.X. Liu, F.W. Tang, H. Lu, Acta Mater. 149, 164 (2018)

[8] Y. Gao, M.Y. Yan, B.H. Luo, S. Ouyang, W. Chen, Z.H. Bai, H.B. Jing, W.W. Zhang, Mater. Sci. Eng. A 687, 259 (2017)

[9] B.K. Yoon, B.A. Lee, S.J.L. Kang, Acta Mater. 53, 4677 (2005)

[10] X. Chen, W.H. Xiong, J. Qu, Q.Q. Yang, Z.H. Yao, Y.Z. Huang, Int. J. Refract. Met. Hard Mater. 31, 56 (2012)

[11] J.J. Gao, L.K. Jiang, J.P. Song, G.X. Liang, J. An, J.C. Xie, J. Inorg. Mater. 32, 891 (2017)

[12] M. Yang, Z.X. Guo, J. Xiong, F.J. Liu, K.F. Qi, Int. J. Refract. Met. Hard Mater. 66, 83 (2017)
[13] V. Bonache, M.D. Salvador, V.G. Rocha, A. Borrell, Ceram. Int. 37, 1139 (2011)

[14] C.B. Wei, X.Y. Song, J. Fu, X.M. Liu, Y. Gao, H.B. Wang, S.X. Zhao, Mater. Sci. Eng. A 552, 427 (2012)

[15] D. Sivaprahasam, S.B. Chandrasekar, R. Sundaresan, Int. J. Refract. Met. Hard Mater. 25, 144 (2007)

[16] V. Bonache, M.D. Salvador, A. Fernández, A. Borrell, Int. J. Refract. Met. Hard Mater. 29, 202 (2011)

[17] Z.Z. Fang, X. Wang, T. Ryu, K.S. Hwang, H.Y. Sohn, Int. J. Refract. Met. Hard Mater. 27, 288 (2009)

[18] W.D. Schubert, H. Neumeister, G. Kinger, B. Lux, Int. J. Refract. Met. Hard Mater. 16, 133 (1998)

[19] A. Petersson, Int. J. Refract. Met. Hard Mater. 22, 211 (2004)

[20] Y.X. Sun, W. Su, H.L. Yang, J.M. Ruan, Ceram. Int. 41, 14482 (2015)

[21] Z. Dong, N. Liu, W.Q. Hu, X.W. Kong, Z.Q. Ma, Y.C. Liu, Mater. Des. 181, 108080 (2019)

[22] H. Chen, Q.M. Yang, J.G. Yang, H.L. Yang, L.Y. Chen, J.M. Ruan, Q.Z. Huang, J. Alloys Compd. 714, 245 (2017)

[23] X.O. Yi, X. Huang, C.B. Liu, D.Q. Yi, Y. Jiang, B. Wang, H.Q. Liu, L.Y. Chen, Acta Metall. Sin. (Engl. Lett.) 30, 146 (2017)

[24] G.P. Zhang, W.H. Xiong, Q.Q. Yang, Z.H. Yao, S. Chen, X. Chen, Int. J. Refract. Met. Hard Mater. 43, 77 (2014)

[25] B. Huang, W.H. Xiong, M. Zhang, Y. Jing, B.L. Li, H.F. Luo, S.Q. Wang, J. Alloys Compd. 676, 142 (2016)

[26] W.Q. Hu, Z. Dong, L.M. Yu, Z.Q. Ma, Y.C. Liu, J. Mater. Sci. Technol. 36, 84 (2020)

[27] L.M. Luo, X.Y. Tan, H.Y. Chen, G.N. Luo, X.Y. Zhu, J.G. Cheng, Y.C. Wu, Powder Technol. 273, 8 (2015)

[28] Z. Dong, N. Liu, W.Q. Hu, Z.Q. Ma, C. Li, C.X. Liu, Q.Y. Guo, Y.C. Liu, J. Mater. Sci. Technol. 36, 118 (2020)

[29] A. Mukhopadhyay, D. Chakravarty, B. Basu, J. Am. Ceram. Soc. 93, $1754(2010)$

[30] D. Duman, H. Gökce, H. Cimenoglu, J. Eur. Ceram. Soc. 32, 1427 (2012)

[31] J.L. Sun, J. Zhao, Z.L. Li, X.Y. Ni, Y.H. Zhou, A.H. Li, Ceram. Int. 43, 2686 (2017) 